\title{
INTERCULTURAL PRAGMATICS
}

\section{EDITOR-IN-CHIEF}

Professor Dr. Istvan Kecskes

State University of New York at Albany

Email: icup@albany.edu

\section{REVIEW EDITOR}

Dr. Jesus Romero-Trillo

Universidad Autónoma de Madrid

Email: jesus.romero@uam.es

\section{TIPP EDITOR}

Professor Dr. Alessandro Capone

University of Messina

Email: acapone@unime.it

\section{EDITORIAL ASSISTANT}

Dr. Melody Hallenbeck Nadeau

Siena College, Loudonville, New York

Email: melody.nadeau@gmail.com

\section{DE GRUYTER MOUTON}




\section{EDITORIAL BOARD}

Patricia Amaral, Indiana University, Bloomington

Mira Ariel, Tel Aviv University

Bruno Bara, University of Torino

Anne Barron, Leuphana University of Lüneburg

Carl S. Blyth, University of Texas, Austin

John W. Du Bois, University of California, Santa Barbara

Noel Burton-Roberts, Newcastle University

Alessandro Capone, University of Messina

Wayne Davis, Georgetown University

Victoria Escandell Vidal, UNED, Madrid

Dirk Geeraerts, University of Leuven

Raymond Gibbs, University of California, Santa Cruz

Rachel Giora, University of Tel Aviv

Michael Haugh, The University of Queensland

Laurence Horn, Yale University

Kasia Jaszczolt, University of Cambridge, UK

Napoleon Katsos, University of Cambridge

Ferenc Kiefer, Hungarian Academy of Sciences

Kepa Korta, Universidad del Pais Vasco

Jacob Mey, University of Southern Denmark

Jacques Moeschler, University of Geneva

Eniko Nemeth, University of Szeged

Steven Pinker, Harvard University

Martin Pütz, University of Koblenz-Landau

Wilfrid Rotgé, Sorbonne IV, Paris

Jiang Wangqi, Peking University

Nellie Wieland, California State University, Long Beach

Anna Wierzbicka, Australian National University

Deirdre Wilson, University of London

Mary Wildner-Bassett, University of Arizona 
ABSTRACTED/INDEXED IN Baidu Scholar · Celdes · Clarivate Analytics (formerly Thomson Reuters): Arts \& Humanities Citation Index; Journal Citation Reports/Social Sciences Edition; Social Sciences Citation Index · CNKI Scholar (China National Knowledge Infrastructure) • CNPIEC · De Gruyter: IBR (International Bibliography of Reviews of Scholarly Literature in the Humanities and Social Sciences); IBZ (International Bibliography of Periodical Literature in the Humanities and Social Sciences) - EBSCO (relevant databases) · EBSCO Discovery Service · Elsevier: SCOPUS · ERIH PLUS (European Reference Index for the Humanities and Social Sciences) · Gale/Cengage · Genamics JournalSeek · Google Scholar · Index Copernicus · J-Gate · JournalGuide · JournalTOCs · KESLI-NDSL (Korean National Discovery for Science Leaders) . Linguistic Bibliography Online · Linguistics Abstracts Online · Microsoft Academic · MLA International Bibliography $\cdot$ Naviga (Softweco) $\cdot$ Primo Central (ExLibris) · ProQuest (relevant databases) $\cdot$ ReadCube $\cdot$ ResearchGate $\cdot$ SCImago (SJR) $\cdot$ Sherpa/RoMEO $\cdot$ Summon (Serials Solutions/ProQuest) · TDNet · UB Frankfurt: BLL Bibliographie Linguistischer Literatur; OLC Linguistik · Ulrich's Periodicals Directory/ulrichsweb · WanFang Data · WorldCat (OCLC).

The publisher, together with the authors and editors, has taken great pains to ensure that all information presented in this work reflects the standard of knowledge at the time of publication. Despite careful manuscript preparation and proof correction, errors can nevertheless occur. Authors, editors and publisher disclaim all responsibility for any errors or omissions or liability for the results obtained from use of the information, or parts thereof, contained in this work.

ISSN 1612-295X · e-ISSN 1613-365X

All information regarding notes for contributors, subscriptions, open access, back volumes and orders is available online at www.degruyter.com/view/j/iprg

RESPONSIBLE EDITOR Istvan Kecskes, School of Education, ED 114, State University of New York at Albany, Albany, NY 12222, USA.

Email: icup@albany.edu

JOURNAL MANAGER Antonia Laimina, De Gruyter, Genthiner Straße 13, 10785 Berlin, Germany, Tel.: +49 (0)30 260 05-380, Fax: +49 (0)30 260 05-250.

Email: antonia.laimina@degruyter.com

RESPONSIBLE FOR ADVERTISEMENTS Claudia Neumann, De Gruyter, Genthiner Straße 13, 10785 Berlin, Germany, Tel.: +49 (0)30 260 05-226, Fax: +49 (0)30 260 05-264, Email: anzeigen@degruyter.com

(C) 2018 Walter de Gruyter GmbH, Berlin/Munich/Boston

TYPESETTING Integra Software Services Pvt. Ltd., Pondicherry, India

PRINTING Franz X. Stückle Druck und Verlag e.K., Ettenheim

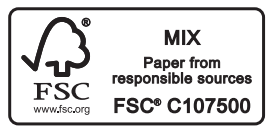





\section{Contents}

Chi-Hé Elder and Michael Haugh

The interactional achievement of speaker meaning: Toward a formal account of conversational inference -593

Baiyao Zuo

Emotive misunderstanding within an extended relevance theory -627

Caroline L. Rieger

How (not) to be rude: Facilitating the acquisition of L2 (im)politeness - 651

\section{Forum}

Ling Zhou and Shaojie Zhang

Reconstructing the Politeness Principle in Chinese: A response to Gu's approach -693

\section{Book Reviews}

Răzvan Săftoiu

Edda Weigand (ed.). The Routledge Handbook of Language

and Dialogue - 723

Bahram Kazemian

Jan Zienkowski, Jan-Ola Östman, and Jef Verschueren, editors. Discursive Pragmatics: Handbook of Pragmatics Highlights — 733 